\title{
QUALITY EVALUATION OF Coffea canephora 'Apoatã' SEEDS FOR ROOTSTOCK PRODUCTION
}

\author{
Marcelo Curitiba Espíndula ${ }^{1}$, Frederico José Evangelista Botelho², Aline da Consolação Sampaio \\ Clemente $^{3}$, Alexsandro Lara Teixeira ${ }^{4}$, Gleice Quele Fonseca Alves ${ }^{5}$, \\ Roseane Maria Evangelista Oliveira ${ }^{6}$
}

(Received: June 30, 2016; accepted: March 14, 2017)

\begin{abstract}
Coffea canephora 'Apoatã' seeds are used for the formation of rootstocks for grafting of C. arabica seedlings. The quality of seeds and the individualization of used genotypes are prevalent factors for the formation of vigorous rootstocks that will enhance the formation of quality seedlings. The aim of the present study was to characterize and evaluate the seed quality of $C$. canephora 'Apoatã' genotypes for potential use of rootstocks for C. arabica species. Were used seeds of 30 C. canephora 'Apoatã' genotypes, obtained from the experimental field of Embrapa Rondônia in Ouro Preto do Oeste, RO, Brazil. The seeds were processed and subjected to germination, first germination count and tetrazolium tests. Moisture, 100seed mass and chemical composition analyses of seeds were also determined. The mass, physiological quality and chemical composition of $C$. canephora 'Apoatã' seeds vary according to the genotype. The variation of the physiological quality of C. canephora 'Apoatã' seeds is not related individually to caffeine, total sugars, ash, ether extract, crude fiber protein and chlorogenic acid. Seed batches of $C$. canephora 'Apoatã' from different genotypes contain seeds of different sizes, being indicated the classification before the processing stage in order to prevent mechanical damages.
\end{abstract}

Index terms: Physiological quality, physical quality, germination, rootstock.

\section{AVALIAÇÃO DA QUALIDADE DAS SEMENTES DE Coffea canephora 'Apoatã' PARA A PRODUÇÃO DE PORTA-ENXERTOS}

RESUMO: Sementes de Coffea canephora 'Apoatã' são utilizadas para formação de mudas de porta enxertos, para enxertia com mudas de C. arabica. A qualidade das sementes e a individualização dos genótipos utilizados é fator preponderante para a formação de porta enxertos vigorosos que potencializará a formação de mudas de qualidade. O objetivo neste trabalho foi caracterizar e avaliar a qualidade de sementes de genótipos de C. canephora 'Apoatã' para potencial utilização de portaenxertos para a espécie C. arabica. Foram utilizadas sementes de 30 genótipos de cafeeiros 'Apoatã' oriundos do Campo Experimental da Embrapa Rondônia em Ouro Preto do Oeste-RO. As sementes foram beneficiadas e submetidas aos testes de germinação, primeira contagem da germinação e tetrazólio. Também foram determinadas a umidade, a massa de 100 sementes e as análises da composição química das sementes. A massa, a qualidade fisiológica e a composição química de sementes de Coffea canephora 'Apoatã' variam em função do genótipo. A variação da qualidade fisiológica de sementes de Coffea canephora 'Apoatã' não está relacionada isoladamente aos teores de cafeína, açucares totais, cinza, estrato etéreo, proteína fibra bruta e ácido clorogênico. Lotes de sementes de C. canephora 'Apoatã' de diferentes genótipos contém sementes com diferentes tamanhos, sendo indicada a classificação antes da etapa de beneficiamento para evitar danos mecânicos.

Termos para indexação: Qualidade fisiológica, qualidade física, germinação, porta enxerto.

\section{INTRODUCTION}

Coffea arabica L. species shows more than $90 \%$ of self-fertilization and is considered as autogamous, thus being very uniform, reason why its cultivars are propagated by seeds. However, the grafting technique has been used primarily to confer nematode tolerance on cultivars susceptible to these diseases (DIAS et al., 2009, 2013).

Besides the possibility of nematode attack control, the use of rootstocks can also improve plant vigor, increase fruit yield, nutrient use efficiency, adaptation to soil conditions and areas with limited rainfall, since some rootstocks have a more developed root system (TOMAZ et al., 2005). However, despite the mentioned benefits, the rootstock can also negatively influence the development of plants (PAIVA et al., 2012; TOMAZ et al., 2005) due to the incompatibility that can occur among some used genotypes.

The 'Apoatã' is the most commonly $C$. canephora cultivar used as rootstock for $C$. arabica cultivars (PAIVA et al., 2012) due to reports of resistance to nematodes from this cultivar (FERREIRA et al., 2011; SANTOS et al., 2017). However, the C. canephora species is

\footnotetext{
1,2,4Embrapa Rondônia - Rodovia BR-364, Km 5,5 - Rural Area - 76.815-800 - Porto Velho - RO - marcelo.espindula@embrapa.br, frederico.botelho@embrapa.br, alexsandro.teixeira@embrapa.br

3,6 Federal University of Lavras/UFLA - Department of Agriculture/ DAG - 37.200 -000 - Lavras - MG - alineagrolavras@gmail.com, roseane-ufla@hotmail.com

${ }^{5}$ Renco Equipamentos S/A, RENCO S/A - Rua da Beira, Br 364, Km 3,5 - 76.815-800 - Porto Velho - RO - gleicequelef@gmail.com
} 
allogamous, which entails great variability among the plants (MONTAGNON; CUBRY; LEROY, 2012; MOTTA et al., 2014; SOUZA et al., 2013). Thus, seeds from the 'Apoatã' cultivar are in practice crossbreeds of genotypes derived from a plant population. Moreover, once the cultivar has been propagated by seed over the years, the populations distributed in Brazil are distinct, being possibly in different generations (AGUIAR et al., 2005).

Based on this genetic variability, it is believed that the different responses found in the literature (DIAS et al., 2008, 2009; TOMAZ et al., 2005) are due to the interactions between the grafted cultivars and the 'Apoatã' populations, since the studies do not report the individualization of the used 'Apoatã' genotypes.

The genotype individualization may imply in the grafting process since seed obtaining and germination, considering that, similarly as $C$. arabica, the genetic variability can lead to different seed sizes (GIOMO; NAKAGAWA; GALLO, 2008), integument resistance (MEIRELES et al., 2007; RUBIM et al., 2010), and concentration of inhibitory substances (ROSA et al., 2007). For instance, some authors suggest that the caffeine present in the endosperm may affect the seed germination (MEIRELES et al., 2007; ROSA et al., 2006), although the influence process is not totally known.

The aim of the present study was to characterize and evaluate the quality of $C$. canephora 'Apoatã' seeds for production of rootstocks for $C$. arabica species.

\section{MATERIAL AND METHODS}

The research was performed at the Seed Laboratory of the Brazilian agricultural research company (Embrapa), in Porto Velho, RO, Brazil, and at the Laboratory of the Seed Sector of the Federal University of Lavras, in Lavras, MG, Brazil. Seeds of C. canephora 'Apoatã' derived from crops with 15 years of age were used, located in the experimental field of Embrapa, in the municipality of Ouro Preto do Oeste, RO, Brazil. The crop was formed based on seeds obtained from the Federal University of Viçosa in the 1990s. A total of 30 genotypes of late maturation cycle were selected, from which fruits were harvested manually in the "cherry" stage. The fruits were pulped in horizontal pulpers model DPMM-02 $\left(\right.$ Pinhalense $^{\circledR}$ ) and the seeds were dried under shade until reaching 13\% moisture. After drying, the seeds were packed in paper bags and kept in air conditioned rooms at $25 \pm 2{ }^{\circ} \mathrm{C}$.
The seeds were processed (elimination of the endocarp) and divided into two batches, being one of $500 \mathrm{~g}$ and another of $100 \mathrm{~g}$. The first batch was sent to the Seed Laboratory of the Embrapa Rondônia where the tests were performed in order to evaluate the physiological and physical quality. The second batch was sent to the Laboratory of the Seed Sector of the Federal University of Lavras where the chemical components of seeds were determined.

The characteristics evaluated were: water content, which was performed before the germination and vigor tests by the ovendrying method at $105{ }^{\circ} \mathrm{C}\left( \pm 3{ }^{\circ} \mathrm{C}\right)$ for $24 \mathrm{~h}$ with results expressed as percentage (wet basis); 100seed mass, performed with eight replicates of 100 seeds and with results expressed in grams; germination, performed with four replicates of 50 seeds per batch, in germinator at $30^{\circ} \mathrm{C}$ and results expressed as percentage of normal seedlings; first germination count, determined together with the germination test, consisted of the normal seedling counting in the 15th day after the test installation (BRASIL, 2009), with the results expressed as percentage; and tetrazolium test, performed according to the methodology of Clemente, Carvalho and Guimarães (2012).

In order to perform the chemical analyses, the green coffee beans were ground for about 1 min in a Tecnal model TE 631/2 mill, adding liquid nitrogen to facilitate milling and prevent oxidation in the samples. After grinding, the samples were conditioned in plastic bottles with a screw cap and stored in a freezer at $-18{ }^{\circ} \mathrm{C}$ until the analyses were performed.

For the determination of moisture, crude protein, total lipids, crude fiber and ash (fixed minerals) in ground coffee seeds, the methods described by the Association of Official Analytical Chemists (AOAC, 1997) were used. Total sugars were determined by the method of Somogyi \& Nelson (NELSON, 1944). Total chlorogenic acids were evaluated according to the methodology proposed by Clifford and Wight (1976), and the caffeine content was determined by spectrophotometry according to methodology proposed by Li, Berguer and Hartland (1990).

Tests were performed using completely randomized design with four replicates. Data were subjected to analysis of variance $(p \leq 0.05)$ and the averages were grouped by Scott-Knott test $(p \leq 0.05)$ through the SISVAR software (FERREIRA, 2008). The association among the evaluated characteristics was measured by Pearson correlation coefficient and its significance was verified by Student's $t$ test $(p \leq 0.05)$. 


\section{RESULTS AND DISCUSSION}

The $C$. canephora genotypes presented different seed mass, being grouped into 13 size classes ranging from $10.34 \mathrm{~g}$ to $22.85 \mathrm{~g}$ (Table 1). Differences among genotypes have also been reported for 89 genotypes from the Embrapa Rondônia active germplasm bank (ROCHA et al., 2013). These results reflect the genetic variability among genotypes, since they constitute a population of individuals derived from allogamy.

Seed size variability was also found in 39 progenies, F4 generation, derived from the C. arabica hybridization, whose evaluation allowed differentiating four grains size groups (PEDRO et al., 2011). These results reinforce that segregating genotypes from the genus Coffea spp. may show high phenotypic variability. These authors also suggest that seed sizes have simple genetic control, but are usually associated with other characteristics, varying according to the age, position in the plant, year, yield and general growth conditions at the time of endosperm and seed development.

Regarding the physiological quality of seeds, the germination test showed different levels of quality, although most of the genotypes showed germination above $70 \%$ (Table 1). Based on the results, it was possible to differentiate six genotype groups with similar germination.

Still based on the first germination count test, variations from 22 to $90 \%$ were observed, which allowed forming four distinct groups, with 27 out of 30 genotypes presenting vigor equal to or above $60 \%$ and thus framing into groups $\mathrm{A}$ and B (Table 1).

In the present study, there was no significant differences among the evaluated genotypes for water and ash (fixed mineral), presenting an average content of $12.48 \%$ and $4.07 \%$, respectively. The other variables caffeine, total sugars, ether extract, crude protein, crude fiber and chlorogenic acids were significant (Table 2).

Regarding the results of the chlorogenic acid contents, significant differences were observed among the genotypes (Table 2), being that the genotype 30 showed the lowest percentage $(7.03 \%)$ and the genotype 22 the highest on $(9.58 \%)$ and the found average content was $8.31 \%$. The results are lower than observed by Aguiar et al. (2005), which found a content of $5.99 \%$ in their studies related to the chemical diversity of $C$. canephora species from the same cultivar under study. Chlorogenic acid (5-CQA) is one of the major soluble phenolic compounds that accumulated in green coffee beans and exert a protective, antioxidant action of aldehydes, which is an important factor in the maintenance of seed quality during storage (ABRAHÃO et al., 2009; MAHESH et al., 2007). However, despite the differences, no correlation was observed between chlorogenic acid contents and physiological quality of the seed.

Germination was negatively correlated with seed size $(-0.64)$, with caffeine content $(-0.33)$, total protein content $(-0.34)$ and ash $(-0.40)$, but correlated positively with the tetrazolium test (0.41) (Table 3).

The first count, as well as the germination, was also negatively correlated with the 100 -seed mass $(-0.65)$, caffeine content $(-0.42)$, total protein content $(-0.37)$ and ash (-0.48), but positively correlated with the tetrazolium test (0.39) (Table $3)$. The 100-seed mass was negatively correlated with the viability of seeds by the tetrazolium test (-0.39) (Table 3).

The negative correlation between physiological quality and seed size differs from those reported for $C$. arabica, whose seeds of smaller size showed lower physiological quality than the larger one (GIOMO; NAKAGAWA; GALLO, 2008). However, it is believed that, for the results found in the present study, the lower germination of higher mass seeds is associated to damages during pulping, since the equipment regulation was not altered for the different fruit sizes, which is confirmed by the negative correlation between the 100 -seed mass and vigor by the tetrazolium test.

With the relationship of the mechanical damages to the low physiological quality of seeds, it can be suggested that the seed classification by size before the processing is an alternative to the use of 'Apoatã' seeds, without distinction of genotypes. However, the separation of seeds by size is a necessary but not sufficient condition for adequate selection in order to estimate their physiological potential and to form quality seedlings. This is because, despite the presented correlation, some genotypes, such as genotypes 14 and 24, showed low indices of 100-seed mass as well as low values of germination and vigor. These results suggest that the physiological quality of the studied seeds is related not only to size but also to other characteristics inherent to the genotype.

The ash content correlated negatively with germination and the first germination count, i.e., the higher the ash content, the lower the germination and vigor of the seed (Table 2). 
TABLE 1 - Physiological quality (WC: Water content; HSW: 100-seed mass; G: Germination; FGC: First germination count; TZ: Tetrazolium) of seeds from 30 C. canephora 'Apoatã' genotypes.

\begin{tabular}{|c|c|c|c|c|c|}
\hline Genotype (Clone) & $\mathrm{WC}$ & HSW & G & FGC & $\mathrm{TZ}$ \\
\hline 1 & 11.20 & $16.11 \mathrm{f}$ & $65 \mathrm{~d}$ & $65 \mathrm{~b}$ & $17 \mathrm{e}$ \\
\hline 2 & 11.21 & $14.70 \mathrm{~h}$ & $77 \mathrm{c}$ & $76 a$ & $65 \mathrm{~b}$ \\
\hline 3 & 10.82 & $22.13 b$ & $57 \mathrm{e}$ & $41 \mathrm{c}$ & $55 \mathrm{~b}$ \\
\hline 4 & 10.98 & $11.78 \mathrm{k}$ & $77 \mathrm{c}$ & $67 \mathrm{~b}$ & $68 \mathrm{~b}$ \\
\hline 5 & 10.74 & $12.62 \mathrm{j}$ & $82 \mathrm{c}$ & $78 \mathrm{a}$ & $83 a$ \\
\hline 6 & 11.28 & $20.07 \mathrm{c}$ & $72 \mathrm{c}$ & $60 \mathrm{~b}$ & $26 \mathrm{~d}$ \\
\hline 7 & 11.06 & 10.981 & $84 b$ & $84 a$ & $63 b$ \\
\hline 8 & 11.18 & $16.30 \mathrm{f}$ & $73 \mathrm{c}$ & $67 \mathrm{~b}$ & $23 \mathrm{~d}$ \\
\hline 9 & 11.82 & $14.73 \mathrm{~h}$ & $74 \mathrm{c}$ & $68 b$ & $51 \mathrm{~b}$ \\
\hline 10 & 11.39 & 11.341 & $78 \mathrm{c}$ & $78 \mathrm{a}$ & $73 a$ \\
\hline 11 & 11.51 & $15.45 \mathrm{~g}$ & $85 \mathrm{~b}$ & $84 a$ & $41 \mathrm{c}$ \\
\hline 12 & 11.77 & $14.10 \mathrm{i}$ & $91 \mathrm{a}$ & $80 \mathrm{a}$ & $63 b$ \\
\hline 13 & 12.63 & $13.91 \mathrm{i}$ & $81 \mathrm{c}$ & $71 \mathrm{~b}$ & $72 \mathrm{a}$ \\
\hline 14 & 11.02 & $14.54 \mathrm{~h}$ & $57 \mathrm{e}$ & $36 \mathrm{c}$ & $28 \mathrm{~d}$ \\
\hline 15 & 10.49 & $22.85 \mathrm{a}$ & $35 \mathrm{f}$ & $22 d$ & $32 \mathrm{c}$ \\
\hline 16 & 10.44 & $12.63 \mathrm{j}$ & $83 b$ & $83 a$ & $61 b$ \\
\hline 17 & 11.21 & $18.10 \mathrm{~d}$ & $79 \mathrm{c}$ & $74 \mathrm{a}$ & $29 d$ \\
\hline 18 & 13.09 & $16.95 \mathrm{e}$ & $83 b$ & $77 \mathrm{a}$ & $10 \mathrm{e}$ \\
\hline 19 & 13.05 & $14.76 \mathrm{~h}$ & $80 \mathrm{c}$ & $80 \mathrm{a}$ & $26 \mathrm{~d}$ \\
\hline 20 & 11.68 & $14.07 \mathrm{i}$ & $79 \mathrm{c}$ & $79 \mathrm{a}$ & $76 a$ \\
\hline 21 & 12.02 & $13.93 \mathrm{i}$ & $83 b$ & $81 \mathrm{a}$ & $64 \mathrm{~b}$ \\
\hline 22 & 11.86 & $14.57 \mathrm{~h}$ & $92 \mathrm{a}$ & $90 \mathrm{a}$ & $66 \mathrm{~b}$ \\
\hline 23 & 11.77 & $16.69 \mathrm{e}$ & $81 \mathrm{c}$ & $78 \mathrm{a}$ & $45 c$ \\
\hline 24 & 11.40 & $11.95 \mathrm{k}$ & $78 \mathrm{c}$ & $64 \mathrm{~b}$ & $58 \mathrm{~b}$ \\
\hline 25 & 11.68 & $12.34 \mathrm{j}$ & $88 \mathrm{a}$ & $85 a$ & $81 \mathrm{a}$ \\
\hline 26 & 11.72 & $14.82 \mathrm{~h}$ & $76 \mathrm{c}$ & $75 a$ & $63 b$ \\
\hline 27 & 11.71 & $14.44 \mathrm{~h}$ & $80 \mathrm{c}$ & $71 b$ & $67 \mathrm{~b}$ \\
\hline 28 & 10.93 & $14.76 \mathrm{~h}$ & $84 \mathrm{~b}$ & $79 a$ & $62 b$ \\
\hline 29 & 11.49 & $16.30 \mathrm{f}$ & $74 \mathrm{c}$ & $67 \mathrm{~b}$ & $15 \mathrm{e}$ \\
\hline 30 & 11.80 & $10.34 \mathrm{~m}$ & $80 \mathrm{c}$ & $78 \mathrm{a}$ & $70 \mathrm{a}$ \\
\hline Average & ----- & 14.94 & 77.30 & 71.48 & 51.76 \\
\hline $\mathrm{CV}(\%)$ & ----- & 2.66 & 6.88 & 8.67 & 18.20 \\
\hline
\end{tabular}

Averages followed by the same letter in the column are not significant different by Scott-Knott test $(\mathrm{p} \leq 0.05)$. 
TABLE 2 - Chemical characteristics (caffeine, total sugars, ash, ether extract, protein, crude fiber and chlorogenic acid) of seeds from 30 C. canephora 'Apoatã' genotypes.

\begin{tabular}{|c|c|c|c|c|c|c|c|}
\hline $\begin{array}{l}\text { Genotype } \\
\text { (Clone) }\end{array}$ & $\begin{array}{c}\text { Caffeine } \\
\%\end{array}$ & $\begin{array}{c}\text { Total } \\
\text { sugars } \%\end{array}$ & Ash \% & $\begin{array}{c}\text { Ether } \\
\text { extract\% }\end{array}$ & $\begin{array}{c}\text { Crude } \\
\text { protein \% }\end{array}$ & Crude fiber\% $\%$ & $\begin{array}{c}\text { Chlorogenic } \\
\text { acids } \%\end{array}$ \\
\hline 1 & $1.48 \mathrm{~h}$ & $4.24 \mathrm{~d}$ & $3.96 \mathrm{a}$ & $5.82 \mathrm{~b}$ & $17.38 \mathrm{e}$ & $12.80 \mathrm{e}$ & $8.29 \mathrm{f}$ \\
\hline 2 & $1.74 \mathrm{f}$ & $4.17 \mathrm{~d}$ & $3.88 \mathrm{a}$ & $5.57 \mathrm{~b}$ & $17.50 \mathrm{e}$ & $14.03 \mathrm{~d}$ & $7.99 \mathrm{~g}$ \\
\hline 3 & $1.97 \mathrm{~b}$ & $3.80 \mathrm{e}$ & $4.04 \mathrm{a}$ & $5.24 \mathrm{c}$ & $17.39 \mathrm{e}$ & $10.10 \mathrm{e}$ & $9.40 \mathrm{~b}$ \\
\hline 4 & $1.75 \mathrm{f}$ & $5.03 a$ & $4.28 \mathrm{a}$ & $5.67 \mathrm{~b}$ & $16.59 \mathrm{f}$ & $12.13 \mathrm{e}$ & $8.91 \mathrm{c}$ \\
\hline 5 & $1.47 \mathrm{~h}$ & $4.00 \mathrm{e}$ & $3.45 \mathrm{a}$ & $6.48 \mathrm{a}$ & $18.18 \mathrm{~d}$ & $13.46 \mathrm{~d}$ & $7.80 \mathrm{~h}$ \\
\hline 6 & $1.72 \mathrm{f}$ & $4.34 \mathrm{c}$ & $4.10 \mathrm{a}$ & $5.23 \mathrm{c}$ & $14.75 \mathrm{~g}$ & $13.66 \mathrm{~d}$ & $8.65 \mathrm{e}$ \\
\hline 7 & $1.62 \mathrm{~g}$ & $4.24 \mathrm{~d}$ & $3.56 \mathrm{a}$ & $4.68 \mathrm{~d}$ & $17.39 \mathrm{e}$ & $13.80 \mathrm{~d}$ & $7.82 \mathrm{~h}$ \\
\hline 8 & $1.77 \mathrm{e}$ & $3.83 \mathrm{e}$ & $4.20 \mathrm{a}$ & $4.10 \mathrm{e}$ & $16.75 \mathrm{f}$ & $14.56 \mathrm{c}$ & $8.69 \mathrm{e}$ \\
\hline 9 & $1.60 \mathrm{~g}$ & $4.61 \mathrm{~b}$ & $3.84 \mathrm{a}$ & $5.38 \mathrm{c}$ & $18.38 \mathrm{~d}$ & $13.73 \mathrm{~d}$ & $7.47 \mathrm{k}$ \\
\hline 10 & $1.90 \mathrm{c}$ & $4.67 \mathrm{~b}$ & $4.17 \mathrm{a}$ & $4.83 \mathrm{~d}$ & $16.62 \mathrm{f}$ & $13.40 \mathrm{~d}$ & $8.77 \mathrm{~d}$ \\
\hline 11 & $1.83 \mathrm{~d}$ & $3.89 \mathrm{e}$ & $4.13 \mathrm{a}$ & $5.99 b$ & $17.38 \mathrm{e}$ & $13.60 \mathrm{~d}$ & $8.92 \mathrm{c}$ \\
\hline 12 & $1.73 \mathrm{f}$ & $4.24 d$ & $4.32 \mathrm{a}$ & $5.68 \mathrm{~b}$ & $17.95 \mathrm{~d}$ & $12.60 \mathrm{e}$ & $8.04 \mathrm{~g}$ \\
\hline 13 & $1.93 \mathrm{c}$ & $4.32 \mathrm{c}$ & $4.07 \mathrm{a}$ & $5.20 \mathrm{c}$ & $20.19 b$ & $14.40 \mathrm{c}$ & $7.72 \mathrm{i}$ \\
\hline 14 & $2.10 \mathrm{a}$ & $4.33 \mathrm{c}$ & $5.96 \mathrm{a}$ & $4.66 \mathrm{~d}$ & $22.88 \mathrm{a}$ & $14.50 \mathrm{c}$ & $7.89 \mathrm{~h}$ \\
\hline 15 & $2.06 \mathrm{a}$ & $4.38 \mathrm{c}$ & $4.35 \mathrm{a}$ & $3.85 \mathrm{e}$ & $20.11 b$ & $16.40 \mathrm{~b}$ & $8.78 \mathrm{~d}$ \\
\hline 16 & 1.051 & $3.61 \mathrm{f}$ & $3.84 \mathrm{a}$ & $3.96 \mathrm{e}$ & $17.85 \mathrm{e}$ & $14.80 \mathrm{c}$ & $7.64 \mathrm{j}$ \\
\hline 17 & $1.29 \mathrm{k}$ & $3.88 \mathrm{e}$ & $4.08 \mathrm{a}$ & $5.28 \mathrm{c}$ & $14.93 \mathrm{~g}$ & $14.46 \mathrm{c}$ & $7.87 \mathrm{~h}$ \\
\hline 18 & $1.61 \mathrm{~g}$ & $4.37 \mathrm{c}$ & $3.89 \mathrm{a}$ & $4.84 \mathrm{~d}$ & $17.50 \mathrm{e}$ & $15.20 \mathrm{c}$ & $8.81 \mathrm{c}$ \\
\hline 19 & $1.80 \mathrm{e}$ & $4.17 \mathrm{~d}$ & $4.08 \mathrm{a}$ & $5.12 \mathrm{c}$ & $18.54 \mathrm{~d}$ & $15.13 c$ & $9.40 \mathrm{~b}$ \\
\hline 20 & $1.49 \mathrm{~h}$ & $4.14 d$ & $4.45 \mathrm{a}$ & $4.59 \mathrm{~d}$ & $17.61 \mathrm{e}$ & $15.46 \mathrm{c}$ & $8.88 \mathrm{c}$ \\
\hline 21 & $1.48 \mathrm{~h}$ & $3.88 \mathrm{e}$ & $4.09 \mathrm{a}$ & $4.37 \mathrm{~d}$ & $14.94 \mathrm{~g}$ & $18.90 \mathrm{a}$ & $8.74 d$ \\
\hline 22 & $2.06 \mathrm{a}$ & $3.86 \mathrm{e}$ & $4.25 \mathrm{a}$ & $4.05 \mathrm{e}$ & $19.41 \mathrm{c}$ & $14.96 \mathrm{c}$ & $9.58 \mathrm{a}$ \\
\hline 23 & $1.51 \mathrm{~h}$ & $4.70 \mathrm{~b}$ & $3.69 \mathrm{a}$ & $3.76 \mathrm{e}$ & $17.51 \mathrm{e}$ & $17.13 b$ & 7.291 \\
\hline 24 & $2.00 \mathrm{~b}$ & $4.41 \mathrm{c}$ & $4.03 \mathrm{a}$ & $5.62 b$ & $17.61 \mathrm{e}$ & $16.00 \mathrm{~b}$ & $7.47 \mathrm{k}$ \\
\hline 25 & $1.43 \mathrm{i}$ & $4.42 \mathrm{c}$ & $3.91 \mathrm{a}$ & $5.91 \mathrm{~b}$ & $16.40 \mathrm{f}$ & $15.20 \mathrm{c}$ & $8.05 \mathrm{~g}$ \\
\hline 26 & $1.93 \mathrm{c}$ & $4.36 \mathrm{c}$ & $4.31 \mathrm{a}$ & $5.39 \mathrm{c}$ & $19.34 \mathrm{c}$ & $18.73 \mathrm{a}$ & $8.87 \mathrm{c}$ \\
\hline 27 & $1.39 \mathrm{j}$ & $4.17 \mathrm{~d}$ & $3.51 \mathrm{a}$ & $4.13 \mathrm{e}$ & $17.61 \mathrm{e}$ & $17.33 b$ & $8.84 \mathrm{c}$ \\
\hline 28 & $2.08 \mathrm{a}$ & $4.11 \mathrm{~d}$ & $3.73 \mathrm{a}$ & $4.96 \mathrm{c}$ & $16.19 \mathrm{f}$ & $16.30 \mathrm{~b}$ & $8.07 \mathrm{~g}$ \\
\hline 29 & $1.70 \mathrm{f}$ & $4.10 \mathrm{~d}$ & $3.90 \mathrm{a}$ & $5.28 \mathrm{c}$ & $18.17 \mathrm{~d}$ & $19.53 \mathrm{a}$ & $7.60 \mathrm{j}$ \\
\hline 30 & $1.82 \mathrm{~d}$ & $4.17 \mathrm{~d}$ & $4.03 \mathrm{a}$ & $5.34 \mathrm{c}$ & $19.49 \mathrm{c}$ & $15.66 \mathrm{c}$ & $7.03 \mathrm{~m}$ \\
\hline Average & 1.71 & 4.22 & 4.07 & 5.03 & 17.75 & 14.93 & 8.31 \\
\hline$\overline{\mathrm{CV}(\%)}$ & 1.39 & 2.60 & 15.99 & 4.32 & 2.81 & 4.67 & 0.60 \\
\hline
\end{tabular}

Averages followed by the same letter in the column are not significant different by Scott-Knott test $(\mathrm{p} \leq 0.05)$. 
TABLE 3 - Pearson correlation coefficient among the analyzed variables (HSW: 100-seed mass; CAF: Caffeine; TS: Total Sugars; ASH: Ash; EE: Ether extract; PT: Protein; CF: Crude fiber; CA: Chlorogenic acid; FGC: First germination count; G: Germination; TZ: Tetrazolium) for seeds from 30 C. canephora 'Apoatã' genotypes.

\begin{tabular}{|c|c|c|c|c|c|c|c|c|c|c|}
\hline & CAF & $\mathrm{TS}$ & $\mathrm{ASH}$ & EE & PT & $\mathrm{CF}$ & CA & FGC & G & $\mathrm{TZ}$ \\
\hline HSW & $0.16^{\text {ns }}$ & $-0.18^{\mathrm{ns}}$ & $0.09^{\mathrm{ns}}$ & $-0.22^{\mathrm{ns}}$ & $0.06^{\text {ns }}$ & $0.06^{\mathrm{ns}}$ & $0.35 \%$ & $-0.64 *$ & $-0.64 *$ & $-0.59 *$ \\
\hline CAF & & $0.21^{\mathrm{ns}}$ & $0.45^{*}$ & $0.03^{\text {ns }}$ & $0.45^{*}$ & $-0.06^{\mathrm{ns}}$ & $0.25^{\mathrm{ns}}$ & $-0.42 *$ & $-0.33 *$ & $-0.05^{\mathrm{ns}}$ \\
\hline $\mathrm{TS}$ & & & $0.09^{\mathrm{ns}}$ & $0.14^{\mathrm{ns}}$ & $0.08^{\text {ns }}$ & $-0.04^{\mathrm{ns}}$ & $-0.14^{\mathrm{ns}}$ & $-0.14^{\mathrm{ns}}$ & $-0.11^{\mathrm{ns}}$ & $0.07^{\mathrm{ns}}$ \\
\hline $\mathrm{ASH}$ & & & & $-0.11^{\mathrm{ns}}$ & $0.52 *$ & $-0.07^{\mathrm{ns}}$ & $0.16^{\mathrm{ns}}$ & $-0.48 *$ & $-0.40 *$ & $-0.22^{\mathrm{ns}}$ \\
\hline $\mathrm{EE}$ & & & & & $-0.12^{\mathrm{ns}}$ & $-0.37 *$ & $-0.17^{\mathrm{ns}}$ & $0.14^{\mathrm{ns}}$ & $0.18^{\mathrm{ns}}$ & $0.14^{\mathrm{ns}}$ \\
\hline PT & & & & & & $0.06^{\mathrm{ns}}$ & $-012^{\mathrm{ns}}$ & $-0.37 *$ & $-0.34 *$ & $-0.01^{\mathrm{ns}}$ \\
\hline $\mathrm{CF}$ & & & & & & & $-0.15^{\mathrm{ns}}$ & $0.13^{\mathrm{ns}}$ & $0.09^{\mathrm{ns}}$ & $-0.07^{\mathrm{ns}}$ \\
\hline $\mathrm{CA}$ & & & & & & & & $-0.08^{\mathrm{ns}}$ & $-0.11^{\text {ns }}$ & $-0.09^{\mathrm{ns}}$ \\
\hline $\mathrm{FGC}$ & & & & & & & & & $0.95 *$ & $0.39 *$ \\
\hline G & & & & & & & & & & $0.41 *$ \\
\hline
\end{tabular}

*Significant and nsNot significant by the t-test $(\mathrm{p} \leq 0.05)$.

Such correlation may be associated with protein and caffeine contents, since these two substances negatively affected the germination and the first germination count. Furthermore, protein and caffeine contents were the only components that correlated positively with ash content (Table 2 ). The negative correlation between physiological quality and caffeine content suggests that this substance may be associated with inhibition of germination and vigor. According to Rosa et al. (2007), the presence of caffeine may cause selfinhibition of coffee seed germination. This fact may explain the low germination and vigor of the genotypes 14 and 24, which showed 2.10 and $2.00 \%$ caffeine, respectively. These results corroborate those reported for $C$. canephora 'Apoatã', in which the exogenous application of caffeine reduced the rooting rate, root length and root fresh mass (ROSA et al., 2006).

Despite the negative correlation and behavior of genotypes 14 and 24, the results of genotypes 22 and 28 counteract with the evidences, since they showed high contents of caffeine (2.06 and $2.08 \%$ ) and high physiological quality (92 and 84\% germination), respectively (Table 1). Behavior similar to caffeine occurred with ash and crude protein contents, since there was a negative correlation for these components, but with low intensity, indicating that high ash or protein content does not reflect in low physiological quality for some genotypes. These results suggest the existence of other endogenous or exogenous factors associated with the quality of C. canephora 'Apoatã' seeds.
The contents of total sugars, total lipids; crude fiber and chlorogenic acid varied according to the studied genotype (Table 3). However, these constituents did not correlate with the physiological quality of coffee seeds (Table 2).

The slow germination of coffee seeds has been attributed to several probable causes, such as physical or chemical barriers, presence of inhibitors or hormonal balances, and probably all these factors can influence it together. Additionally, seed germination is a complex process in which innumerable metabolic events are involved and several factors act simultaneously, under genetic control and under influence of several external factors (ROSA et al., 2006).

The results of the present study suggest that the physiological quality of $C$. canephora 'Apoatã' seeds varies according to the genotype that originated such seeds. However, the evaluated chemical components did not allow inferring about the origin of such variation.

\section{CONCLUSIONS}

The physiological quality and chemical composition of $C$. canephora 'Apoatã' seeds vary according to the genotype.

The variation of the physiological quality of $C$. canephora 'Apoatã' seeds is not related individually to caffeine, total sugars, ash, ether extract, crude fiber protein and chlorogenic acid.

Seed batches of $C$. canephora 'Apoatã' from different genotypes contain seeds of different 
sizes, being indicated the classification before the processing stage in order to prevent mechanical damages.

\section{ACKNOWLEDGEMENTS}

The authors would like to thank the Brazilian Coffee Research and Development Consortium.

\section{REFERENCES}

ABRAHÃO, S. A. et al. Compostos bioativos em café integral e descafeinado e qualidade sensorial da bebida. Pesquisa Agropecuária Brasileira, Brasília, DF, v. 43, n. 12, p. 1799-1804, 2009.

AGUiAR, A. T. E. et al. Diversidade química de cafeeiros na espécie Coffea canephora. Bragantia, Campinas, v. 64, n. 4, p. 577-582, 2005.

ASSOCIATION OF OFFICIAL ANALYTICAL CHEMISTS. Official methods of analysis. Washington, DC, 1997. 726 p.

BRASIL. Ministério da Agricultura, Pecuária e Abastecimento. Regras para análise de sementes. Brasília, DF, 2009. 395 p.

CLEMENTE, A. C. S.; CARVALHO, M. L. M.; GUIMARAES, R. M. Suitability of the tetrazolium test methodology for recently harvested and stored coffee seeds .Ciência e Agrotecnologia, Lavras, v. 36, n. 4, p. 415-423, jul./ago. 2012.

CLIFFORD, M. N.; WIGHT, J. The measurement of feruloylquinic acids and caffeoylquinic acids in coffee beans: development of the technique and its preliminary application to green coffee beans. Journal of the Science of Food and Agriculture, London, v. 27, n. 1, p. 73-84, Jan. 1976.

DIAS F. P. et al. Desenvolvimento de cafeeiros enxertados 'Apoatã IAC 2258' cultivados em recipiente de 250 litros. Ciência e Agrotecnologia, Lavras, v. 32, n. 2, p. 385-390, mar./abr. 2008.

Desenvolvimento de mudas de cultivares de café arábica enxertadas sobre Apoatã IAC 2258. Semina: Ciências Agrárias, Londrina, v. 34, n. 1, p. 29-36, 2013.

. Produção de cafeeiros Coffea arabica L. pés francos, auto-enxertados e enxertados em Apoatã IAC 2258. Ciência e Agrotecnologia, Lavras, v. 33, n. 2, p. 484-487, mar./abr. 2009.
FERREIRA, A. D. et al. Desenvolvimento vegetativo de cultivares de Coffea arabica L. enxertados em Apoatã IAC 2258 (Coffea canephora Pierre ex A. Froehner). Coffee Science, Lavras, v. 6, n. 1, p. 20-26, set. 2011.

FERREIRA, D. F. SISVAR: um programa para análises e ensino de estatística. Revista Symposium, Lavras, v. 6, p. 36-41, 2008.

GIOMO, G. S.; NAKAGAWA, J.; GALlO, P. B. Beneficiamento de sementes de café e efeitos na qualidade fisiológica. Bragantia, Campinas, v. 67, n. 4, p. 1011-1020, 2008.

LI, S.; BERGUER, J.; HARTLAND, S. UV spectrofotometric determination of Theobronine and caffeine in cocoa beans. Analytica Chemica Ancta,Amsterdam, v. 232, p. 409-412, 1990.

MAHESH, V. et al. Functional characterization of two p-coumaroyl ester 3'-hydroxylase genes from coffee tree: evidence of a candidate for chlorogenic acid biosynthesis. Plant Molecular Biology, Dordrecht, v. 64, n. 1/2, p. 145-159, 2007.

MEIRELES, R. C. et al. SECAFÉ: metodologia para acelerar a germinação das sementes de café. Revista Brasileira de Sementes, Brasília, DF, v. 29, n. 3, p. 90-96, 2007.

MOTTA, L. B. et al. Molecular characterization of arabica and Conilon coffee plants genotypes by SSR and ISSR markers. Brazilian Archives of Biology and Technology, Curitiba, v. 57, n. 5, p. 728-735, out. 2014.

MONTAGNON, C.; CUBRY, P.; LEROY, T. Amélioration génétique du caféier Coffea canephora Pierre: connaissancesacquises, stratégieset perspectives. Cahiers Agriculture, Paris, v. 21, n. 2/3, p. 143-153, Mar./June 2012.

NELSON, N. A photometric adaptation of the Somogyi method for the determination of glucose. Journal of Biological Chemistry, Baltimore, v. 153, p. 375-380, 1944.

PAIVA, R. F. et al. Comportamento de cultivares de cafeeiros C. arabica L. enxertados sobre cultivar 'Apoatã IAC 2258' (Coffea canephora). Ciência Rural, Santa Maria, v. 42, n. 7, p. 1155-1160, 2012.

PEDRO, F. C. et al. Comportamento agronômico de progênies F4 de cafeeiros oriundos do cruzamento entre os cultivares Mundo Novo e Catuaí. Revista Ceres,Viçosa, v. 58, n. 3, p. 315-322, 2011. 
ROCHA, R. B. et al. Caracterização e uso da variabilidade genética de banco ativo de germoplasma de Coffea canephora Pierre ex Froehner. Coffee Science, Lavras, v. 8, n. 4, p. 478-485, out./dez. 2013.

ROSA, S. D. V. F. et al.Inibição do desenvolvimento in vitro de embriões de coffea por cafeína exógena. Revista Brasileira de Sementes, Brasília, DF, v. 28, n. 3, p. 177-184, 2006.

Pré-embebição: efeitos na germinação; crescimento de plântulas e teor de cafeína em sementes de cafeeiro. Coffee Science, Lavras, v. 2, n. 1, p. 69-78, dez. 2007.

RUBIM, R. F. et al. Tratamento com hipoclorito de sódio para remoção do pergaminho e aceleração da germinação de sementes de café conilon. Revista Brasileira de Sementes, Londrina, v. 32, n. 4, p. 8898, 2010.

SANTOS, A. V. et al. Reaction of Coffea canephora clones to the root knot nematode, Meloidogyne incognita. African Journal of Agricultural Research, Nairobi, v. 12, n. 11, p. 916-922, Mar. 2017.

SOUZA, F. F. et al. Molecular diversity in Coffea canephora germplasm conserved and cultivated in Brazil. Crop Breeding and Applied Biotechnology, Londrina, v. 13, p. 221-227, 2013.

TOMAZ, M. A. et al. Porta-enxertos afetando o desenvolvimento de plantas de Coffea arabica L. Ciência Rural, Santa Maria, v. 35, n. 3, p. 570-575, 2005. 